\title{
Psychological Obstacles of the PTUN Judges and Regulatory Reconstruction of the DKPP Verdict in Enforcing the General Election Organization Code of Ethics
}

\author{
Rudhi Achsoni ${ }^{1}$, Istislam², Herman Suryokumoro², Aan Eko Widiarto ${ }^{2}$ \\ ${ }^{1}$ Doctorate Student Universitas Brawijaya Malang, ${ }^{2}$ Associate Professor, Universitas Brawijaya Malang
}

\begin{abstract}
Verdict of the DKPP in Article 458 clause (13) in the Law No. 7 of 2017 on the General Election is final and binding. Yet, the implementation stage of the "final and binding" phrase causes multi-interpretation. Thus, there are some verdicts of the General Election Honorary Organizing Council (DKPP) which underwent legal efforts to the State Administration Court (PTUN). As a form of ius constituendum, the writer suggests that there should be a regulatory reconstruction on the verdicts of the DKPP in upholding the code of ethics in organizing the general election, by classifying that the verdicts of the DKPP is an ethical verdict; thus it is not proper to be corrected by the legal verdict in the PTUN. The room for correction will be opened by mandating it to the Court of Ethics. The ethical verdict corrected in the PTUN will risk the judges' independence. It is highly possible that they will experience psychological pressure in making a verdict on the general election ethic violation in their capacity as Civil servant (PNS) who are institutionally under the Ministry of State Apparature Empowerment (Menpan), which specifically the minister is a political official which is chosen by the president.
\end{abstract}

Keywords: Reconstruction, DKPP Verdict, Code of Ethics in Establishing the General Election, and Psychology of Judges.

\section{Introduction}

This research is entitled the regulatory reconstruction of the DKPP verdict in upholding the code of ethics in establishing the general election and also the psychological obstacles of the State Administration Court. The legal problem starts from the blanked norm in Article 458 clause (13) of the Law No. 7 on 2017 on the General Election. This article states that, "The verdict as aforementioned in clause (10) is final and binding." In the explanation of that Article, it has been clearly stated that from the phrase "final and binding", the DKPP verdict must be implemented by the president, the General Election Commission (KPU), the Provincial General Election Commission (KPUD), the External Monitoring Body (Bawaslu), and the Provincial External Monitoring Body (Bawaslu Provinsi)

Based on the writers' observation, the parties which carry out legal efforts to the PTUN uses the basis of the Constitutional Court Decree No. 31/PUU-XI/2013 ${ }^{1}$. The
Constitutional Court Decree basically explains that the DKPP verdict is binding to the president, the General Election Commission, KPUD, the City/Regency General Election Commission, and the External Monitoring Body, but not final to the justice-seekers ${ }^{2}$.

On one side, in the perspective of the state administrative law, the Constitutional Court's Decree may be understood. But, from the aspect of the State Administrative Law, the writer believes that it is improper to position the DKPP the same as other State Administration organs. ${ }^{3}$ and also the independence in ethical decisions. The DKPP verdict which cancels the general election organizer, from the KPU or Bawaslu due to the ethical codes, cannot directly be applied.

If the legal effort to the PTUN is deemed as correct, thus the PTUN Verdict will in the end be measured and evaluated based on the truth according to the legal perspective. It will be decided upon with the risk of the PTUN judges' lack of independence as PNS who 
are under the Menpan. There is a high chance for psychological pressure, Apart from that, this is because the DKPP ethical code court assembly is psychologically more independent than the PTUN trial judges. This is because the former is not under the government, which is different from the latter, who has the capacity as PNS.

The problem which arises regarding the DKPP verdict is that if this is allowed, it will cause an uncertainty of law. The number of KPU which carry out legal efforts to the PTUN will also increase, as every DKPP verdict is issued with the order to lay off a general election organizer. Then, the laid off general election organizer will directly carry out legal efforts to the PTUN. This precedent becomes improper when the government (which is affiliated with the parties in power) have a great potential to pressure the PTUN judges who are PNS with the excuse of loyalty.

\section{Research Method}

This is a legal-normative research. ${ }^{4}$ The function of a legal research is to obtain coherent truth, ${ }^{5}$ which is seeking suitability between the analyzed object and the referral regulations and principles. ${ }^{6}$ The approaches used in this research are the statute approach, the case approach, the historical approach, and the conceptual approach. $^{7}$

\section{Discussion}

Due to the complexity of issues in organizing a general election, it is not enough to only depend on legal principles to achieve a good organization of the general election. Yet, it must be completed with ethical codes. This is necessary to create a demand to the public officials so as to have a high moral standard, so that they may maintain the trust of the people ${ }^{8}$.

The main source of this conflict is the unclear regulations on the DKPP final verdict's character in Article 458 clause (13) of the Constitution No. 7 of 2017. The phrase "final and binding" in the implementation stage has issues. Based on the results of the research, until February 2020, there are twenty-two cases of DKPP verdicts brought to the PTUN for legal efforts, as obtained from a personal communication with the Head of the Court Section, DKPP, Republic of Indonesia (February 2020).

In the processing stage in the PTUN, there were eighteen verdicts related to the DKPP verdicts. From that number, fourteen were granted, four were rejected. In the cassation stage in the Supreme Court, there were sixteen verdicts regarding the DKPP verdict execution. From that number there were ten KPU laid off by the DKPP who then won in the Supreme Court stage. Then, six cases were rejected.

The writer suggests that the DKPP existence with the final character of its ethical verdict is a form of innovation on some of the general election issue complexities. Meanwhile, regarding the perspective which positions the DKPP verdict correctable by the PTUN, it is sourced from the inextensive thought on the judicial power, where the judicial poers is only based on Article 24 clause (2) of the 1945 Constitution.

If it is only based on Article 24 clause (2) of the 1945 Constitution, thus there is a perspective that the DKPP only has a position as an organ of the State Administration. Thus, their products are included as part of the State Administration verdicts. Yet, it must be observed that in Article 24 clause (2) of the 1945 Constitution, it also states, "Other bodies whose function is related to the judicial power is regulated in the constitution." The idea to give a room for the DKPP verdict correction to the Court of Ethics may be deemed as legally correct. This is because apart from the fact that the formation of the DKPP is strengthened by the Law No. 7 of 2017 on the General Election, according to the writer, this Council also has a constitutional basis, which is Article 24 clause (3) of the Constitution of 1945.

The DKPP verdicts on the general election ethical violation is related to the political interests of the general election participants. Meanwhile, the status of the DKPP assembly is not a governmental organ, thus it is psychologically possible to be independent. The contrary happens if the DKPP verdicts are then corrected by the PTUN judges who tend to have their position intervened as PNS. They are psychologically under the influence of the government in political issues by the parties in power of the affiliated power. Judges who are psychologically under pressure will not be able to decide clearly and objectively.

This is because a good verdict of the judges must contain three main considerations, which are the philosophical justice, the sociological justice, and the judicial justice ${ }^{10}$, which cannot be obtained if the judge is psychologically pressured in their capacity as a PNS.

The improper DKPP verdicts are brought to the 
PTUN for legal effort, as this Court is part or an organ of the government. Thus, hierarchically, the position of the PTUN judges is under the Menpan. Then, psychologically, the independence of this court's judges will be disturbed in deciding upon the ethical issues in establishing the general election. There are some aspects which are currently related to the judicial position, such as the judge recruitment, financial rights, career path/stratification according to the rank, and facilities, which still follow the regulatory standard of civil servants (PNS), as state by Marzuki. ${ }^{11}$ Such position will psychologically cant maintain themselves from the intervention of authority. Giving a room to correct the DKPP verdict to the PTUN is the same as opening a room for intervention.

The writer suggests that the formation of the DKPP is part of a legal innovation on the general election. According to Oemar Seno Adji, "A court which is independent and uninfluenced are indispensable requirements for a state of law". Independent means that there is no intervention from the executive and legislative powers in carrying out the judiciary functions ${ }^{12}$.

According to Bagir Manan, the judicial assembly which is deemed as unneutral or taking sides may be due to the influence of power, where the judicial assembly is psychologically powerless in facing the wills of those in higher power. The judges of the PTUN also face a psychological dilemma in facing the governmental influences when deciding upon the ethical code verdicts of the KPU in their status as PNS who are bound with their obligation to be loyal to the government (in this case the parties in power of the coalisions in the government).

Based on the description above, it can be concluded that justice will be better enforced if supported by a system of law and a system of ethics where both synergize to uphold justice. In the rule of law system exists the code of law, which is equipped with the court of law or a law-enforcing institution (the legal court). Also, in the rule of ethics, there is the code of ethics which surely needs the court of ethics, which is an institution which upholds the ethics. ${ }^{14}$

Then, regarding the interpretation of the DKPP verdict which is final and binding in Article 458 clause (13) of the Law No. 7 of 2017 and also impact of the Constitutional Court decree No. 31/PUU-XI/2013 which has caused some problems, the general election legal frameworks should be formulated as comprehensively as possible, so as to avoid multi-interpretation. It is so that it may easily be understood. It must answer issues regarding the general election to create and to make sure that the general election runs democratically.

The writer suggests that the DKPP verdict has an important relation to the quality of the organization and the result of the general election. So, apart from the urgency of the regulation on the DKPP verdict's final character, there should also be a room for appeal on this verdict. According to the writer, this thought is in line with the ratio decidendi or the legal consideration in the Constitutional Court Decree No. 31/PUU-XI/2013, because in this decree, the Constitutional Court principally states that the the DKPP verdict is binding to the president, the General Election Commission (KPU), KPUD, the City/Regency General Election Commission, and the External Monitoring Body.

Departing from the thoughts above, it should be noted that the room for appeal is not the room for legal appeal by the PTUN. But it is the ethical appeal room by the ethical court, which in this case is the Court of Ethics. The writer believes that the room for appeal or correction is important to be opened to make sure that the DKPPis more careful and accurate in issuing a product of verdict.

The influence of governmental power in the PTUN opens the chance for misuse of power by the government regarding the handling of the general election code of ethics violation for the sake of power. The PTUN judicial power is constitutionally predicted to not be able to give a verdict without psychological pressure, considering that their status as PNSs are subordinantes of the government. The judges' status as the PNS makes it possible for intervention of the judicial freedom, because the structural psychological, corporal, and bureaucratic characteristics bring or demand certain bindings ${ }^{15}$.

In the context of the DKPP verdict regulations, the writer agrees that appeal may only be carried out on one stage, and it must be carried out by the ethical institutions instead of the legal ones. Based on that, the DKPP verdict regulatory reconstruction in upholding the ethical codes of the general election organization becomes urgent.

\section{Reconstruction of the Law No. 7 of 2017 on the}

General Election: There should be a revision on Article 458 clause (13) on the Constitution No. 7 of 2017, which states that the DKPPverdicts are final 
and binding. The writer suggests that the "final and binding" phrase should be changed into, "The DKPP verdict must be implemented by the president, the General Election Commission, KPUD, Bawaslu and the Provincial External Monitoring Body."

After there is an addition to that article, there should be two new clauses, which are clause (14) and clause (15). On clause (14) it should state that if there are parties who object the verdict as aforementioned in clause (10), an effort of ethics may be brought to the Court of Ethics. Then, on clause (15), it should state that the Court of Ethic's verdict on the code of ethic alleged violation as meant in clause (11) is final and binding, and cannot be a case object in the courtly environment of the Supreme Court.

\section{Reconstruction of the Law No. 9 of 2004 on the} Change of the Law No. 5 on 1986 on the DKPP: The writer suggests that in the reconstruction, there is an additional criterion that the verdict regarding the DKPP verdict is not included as an object which may be proposed to the PTUN. The regulation regarding the object which cannot be proposed to the PTUN is written in Article 2 of the Law No. 9 of 2004 regarding the change of the Law No. 5 of 1986 regarding the PTUN, which states that, "Those not included in the definition of the PTUN verdict according to this Constitution are as follows:" First is the PTUN verdict which is an action of the civil code. Second is the PTUN verdict which is a common regulation. Third is the verdict which still needs approval. Fourth is that which is issued based on the stipulations of the criminal code and the code of criminal law procedure or other laws which have the character as criminal codes. Fifth is the verdict which is issued as a result of investigation from the judicial bodies based on the stipulations of the constitutional regulations which apply. Sixth is the PTUN verdict regarding the administration of the Indonesian National Army. Seventh is the verdict of the General Election Commission, Based on the seven exeptional verdicts above, the writer suggests that an additional criterion is added, where that criterion should be placed in Article 2 letter $h$ number eight.

\section{Conclusion}

An ethical verdict is different from a legal one. This is because the institutions which issue them and the references which become their bases are also different.
Thus, it is not proper to investigate the validity of an ethical verdict - which is sourced from ethical principles - at the PTUN, in which the basis is the legal principles.

The revision of the General Election law is necessary to state that the DKPP verdict must be implemented by the the President, the General Election Commission, KPUD, the External Monitoring Body, and the Provincial External Monitoring Body. The room for correction or the cassation of the DKPPverdict will be carried out by the Court of Ethics instead of the PTUN, as the latter has a psychological obstacle in handling the cases on the general election code of ethics violation as a PNS. These judges will psychologically have trouble if the government then intervenes or pressures them to make decisions regarding the general election code of ethics violation which menguntungkan the parties in power or the coalitions in the government.

\section{Source of Funding: Author}

\section{Ethical Clearance: Yes}

\section{Conflict of Interest: No}

\section{References}

1. Examination of the Law No. 15 on the General Election organization 2011 has been changed into the Law No. 7 regarding the General Election 2017 (Indonesia).

2. Decree of the Constitutional Court No. 31/PUU$\mathrm{XI} / 2013$ (Indonesia).

3. Asshiddiqie J. Principles of the Indonesian postreformation state administrative law. Jakarta: Bhuana Ilmu Populer; 2007. 25 p.

4. Ellyani E, Dimyati K, Wardiono K, Absori A, Budiono A, Sakroni. The position medical forensics and visum et repertum in adultery (overspel) cases in the Jenang Kutei traditional trial in Bengkulu, Indonesia. IJFMT. 2020; 14(1):1463-7.

5. Marzuki PM. Introduction to legal studies. Jakarta: Kencana Prenada Media Group; 2008. 47 p.

6. Ibrahim J. Theory and methodology of legal normative research. Malang: Banyumedia Publish; 2006. 57 p.

7. Marzuki PM. Legal research. Jakarta: Prenada Media Group; 2016. 133 p.

8. Sumaryono E. Ethics of legal profession: norms for law enforcers. Yogyakarta: Kanisius; 1995. 165 p. 
9. Adonara FF. Principles of freedom of justice in deciding the case as a constitutional mandate. Jurnal Konstitusi. Jun 2015;12(2):221.

10. Yudisial K. Straightening the direction of judicial power management. Jakarta: Sekretariat Jenderal Komisi Yudisial; 2018. 26 p.
11. Adji OS. The free court of a legal state. Jakarta: Erlangga; 1987. 46 p.

12. Asshiddiqie J. Ethical justice and the ethics of the constitution. Jakarta: Sinar Grafika; 2010.

13. Wulansari EM. The professional regulations on the judicial position. Rechtfindings. 2016;4(2):22. 